\title{
Innovative vine training system as a strategy for adaptation to climate change on Verdicchio
}

\author{
Vania Lanari $^{1}$, Edoardo Dottori ${ }^{1}$, Tania Lattanzi ${ }^{*}$, Luca Pallotti ${ }^{1}$, and Oriana Silvestroni ${ }^{1}$ \\ ${ }^{1}$ Dipartimento di Scienze Agrarie, Alimentari ed Ambientali, Università Politecnica delle Marche, Via delle Brecce Bianche, 60131, \\ Ancona, Italia
}

\begin{abstract}
Grape quality is endangered by thermal increase caused by climate change. Hence, the necessity to find adaptation solutions moved research activities in the last few years towards experimenting innovative management techniques. In this trial an innovative training system, called High Cane, was compared with the traditional Guyot. High Cane trained vines showed lower photosynthetically active solar radiation values at the fruiting zone, a higher number of shoots per vine and total yield. At harvest, High Cane proved to have some effects in slowing down ripening, i.e. showing lower sugar content, higher titratable acidity and lower $\mathrm{pH}$. The innovative training system is a candidate to be a valid strategy for the adaptation to the effects of climate change.
\end{abstract}

\section{Introduction}

The thermal increase due to the changed climatic context is destined to continue [1], therefore the vineyard management acquires an increasing interest in addressing the challenges caused by climate change, including the excessive and accelerated grape ripening. The musts deriving from these rapidly ripening grapes are often unbalanced and the wines produced, with a high alcohol content, deviate from the most recent evolution of taste of the global market, characterized by the demand for fresh wines with moderate alcohol content.

In the last decade, studies have been carried out aimed at developing and fine-tuning techniques capable of slowing down the phenology and ripening of grapes $[2,3,4,5,6,7,8,9]$.

Among these, the flexible techniques able to 'control canopy efficiency' $[3,4,5]$ even if applied late in the season, when critical conditions occur, have shown interesting results on numerous varieties. Other techniques considered not flexible, because to be applied at the beginning of vegetative season, have been able to slow down the phenology of the vine with significant effects on the yield and berry composition of the grapevines, mainly spur pruned. Late pruning, extensively studied in recent years on spur pruned cordon training systems and on varieties with high fertility of basal buds $[6,7,8,9]$, can be applied less easily on vines that require long pruning [10].

It is therefore necessary to outline, even for varieties with low fertility of the basal buds that require long pruning, innovative vineyard management strategies aimed at increasing their resilience and increasing adaptation to climate change. The present study was aimed at the development of an innovative vine training system suitable for varieties with low fertility of the basal buds, easy to manage and capable of slowing down grape ripening.

\section{Materials and Method}

The study was carried out on a vineyard of about 1 ha managed under organic farming and located in San Paolo di Jesi (AN), within the "Verdicchio dei Castelli di Jesi" appellation area. The vines were planted in 2017 with certified virus-free cuttings of cv. Verdicchio grafted onto 420A rootstock, oriented in a north-south direction and planted at $1.10 \mathrm{~m}$ in-row vine spacing and $3 \mathrm{~m}$ between rows spacing (3030 vines/ha). In March 2020, in three plots of three rows each, the vines previously trained with the Guyot system were transformed into the innovative "High Cane" training system: the supporting wire was raised bringing it to $1.1 \mathrm{~m}$ from the ground from the $0.9 \mathrm{~m}$ of the previous system, a traditional Guyot (Fig. 1). The new training system, therefore, featuring the supporting wire at $1,1 \mathrm{~m}$ from the ground, and two pairs of foliage wires placed respectively at 1,35 and $1,70 \mathrm{~m}$ from the ground, increased the height of the fruiting zone from the ground, in comparison to Guyot system.

The new system therefore intends to slow down the ripening of the grapes by acting on two sides: i) reduce the leaf surface of the vines by lowering the height of the canopy so as to decrease the canopy/crop load ratio; ii) increase the distance from the ground of the bunches, thus limiting the amount of heat radiated from the soil that reaches the fruiting zone.

At the beginning of June 2020, a topping of the shoots was carried out on the grape vines trained to High Cane and Guyot systems. A randomized block design with 3

\footnotetext{
*Corresponding author: t.lattanzi@staff.univpm.it
} 
blocks of 3 rows for each training system was used for this trial. Data were taken on the central row of each plot, on 8 vines per row (24 sampling vines per training systems). Before harvest, the height of the canopy was measured in the central part of each sampling vine and canopy thickness was determined at the level of the fruiting zone and the upper pair of foliage wires.

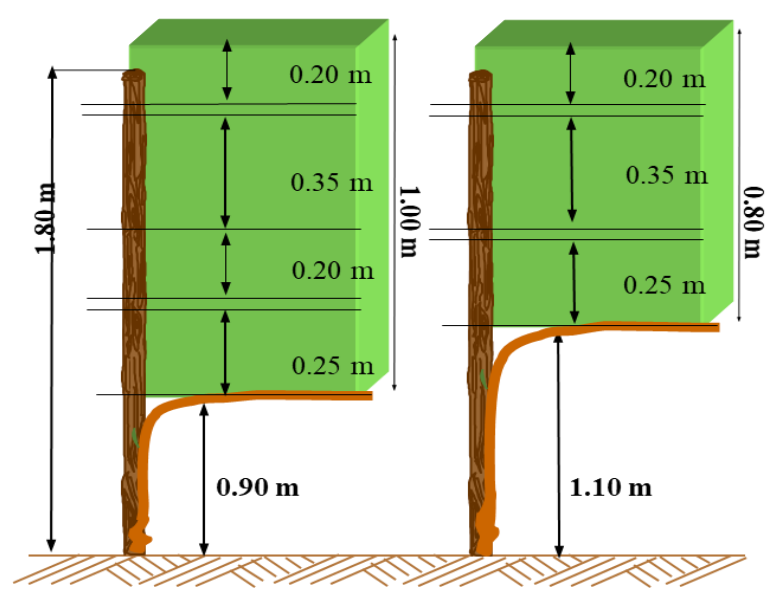

Figure 1. Scheme of the training systems comparing traditional Guyot (left) and High Cane (right).

Before harvest (September $15^{\text {th }}$ ), the photosynthetically active solar radiation was measured at the level of the fruiting zone in the central part of the sample vines, using the Ceptometer (AccuPAR - DECAGON $950 \mathrm{NE}$ Nelson Court - Pullman, WA 99163). Yield per vine was measured at harvest, on 16 September 2020, when grape bunches were picked and the total number of bunches per vine was counted and weighed. Berry sugar accumulation and titratable acidity were measured weekly from the beginning of August to harvest on a sample of 100 berries per plot. Total soluble solids were measured with a temperature-compensating Maselli LR01 digital refractometer (Maselli Misure, Parma, Italy); $\mathrm{pH}$ with a Crison $\mathrm{pH}$ meter (Crison Instruments, Barcelona, Spain) by a glass electrode; titratable acidity with a Crison Titrator (Crison Instruments) using $0.25 \mathrm{~N}$ $\mathrm{NaOH}$ to a $\mathrm{pH} 7.00$ endpoint, expressed as $\mathrm{g} / \mathrm{L}$ of tartaric acid equivalent.

The data were processed and subjected to statistical analysis of variance. Mean separation was performed by t-test $(\mathrm{p}=0.05)$.

\section{Results and discussions}

The High Cane vines showed a significantly lower height of the canopy and leaf area per shoot (data not shown). We note a lower PAR in the fruiting zone, due to the different canopy dimension (Fig. 2). In fact, the High Cane training system had a wider canopy in the distal zone, due to the growth of laterals, stimulated by the topping intervention, thus reducing the amount of the light on the clusters during ripening.

Berry weight in vines trained with High Cane was higher than in vines trained with Guyot of about $+0.4 \mathrm{~g}$ at the DOY 218 and $+0.2 \mathrm{~g}$ at harvest (DOY 260) (Fig. 3, above). Similarly, the sugar concentration resulted markedly lower in High Cane vines since the first sampling, showing a difference of $3.47{ }^{\circ}$ Brix, at harvest, in comparison to Guyot vines (Fig. 3, below).
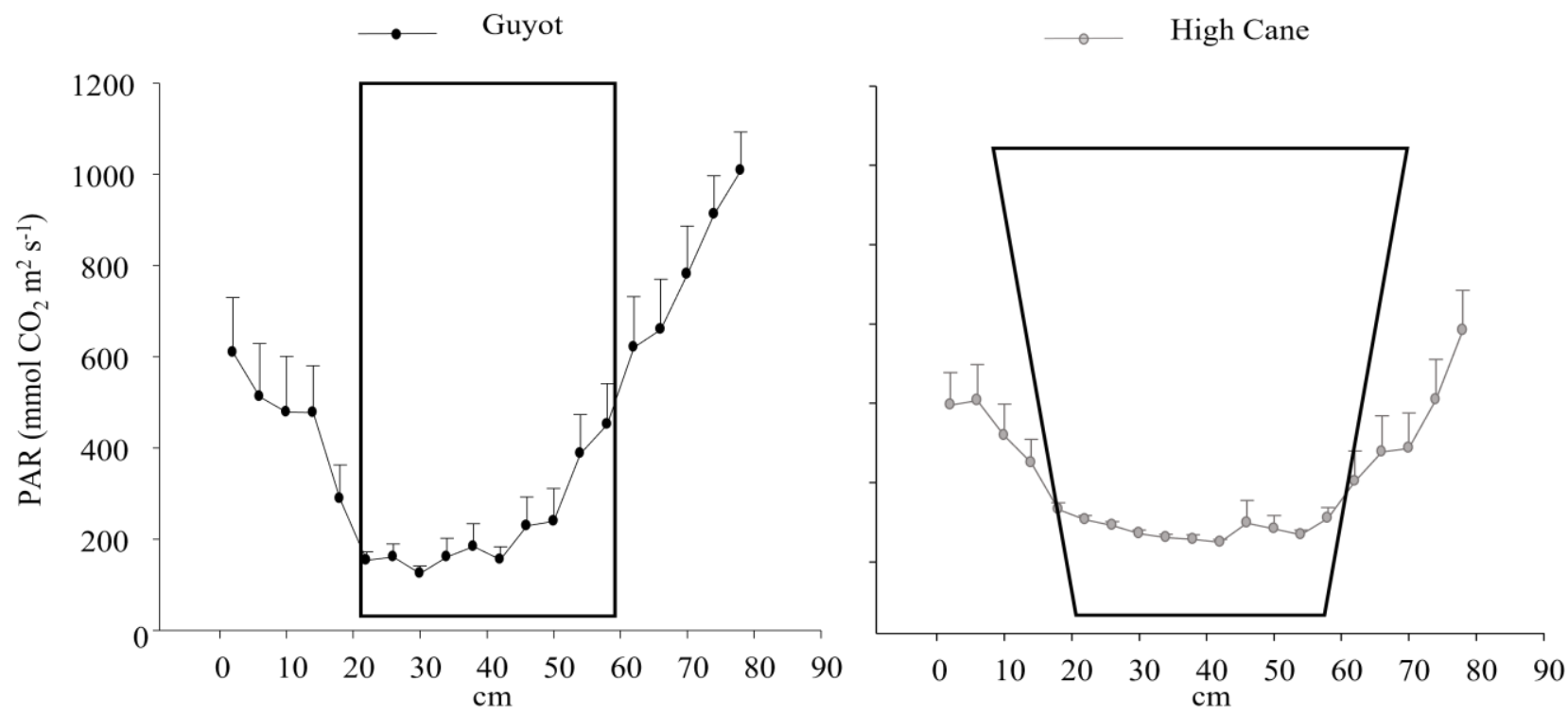

Figure 2. Photosynthetically active solar radiation at the level of the fruiting zone and canopy dimensions of the two training systems.

From the first sampling, significant differences in titratable acidity and $\mathrm{pH}$ emerged between the two different theses, and remained until the harvest (Fig. 4).
The differences in berry ripening between the two training systems can be attributed to several causes that can be linked to crop load. The High Cane trained vines, 
in comparison to Guyot ones, were pruned longer and showed a higher number of shoots per plant (16 versus 13) and of bunches per plant, which resulted in the higher yield per vine (Tab. 1).

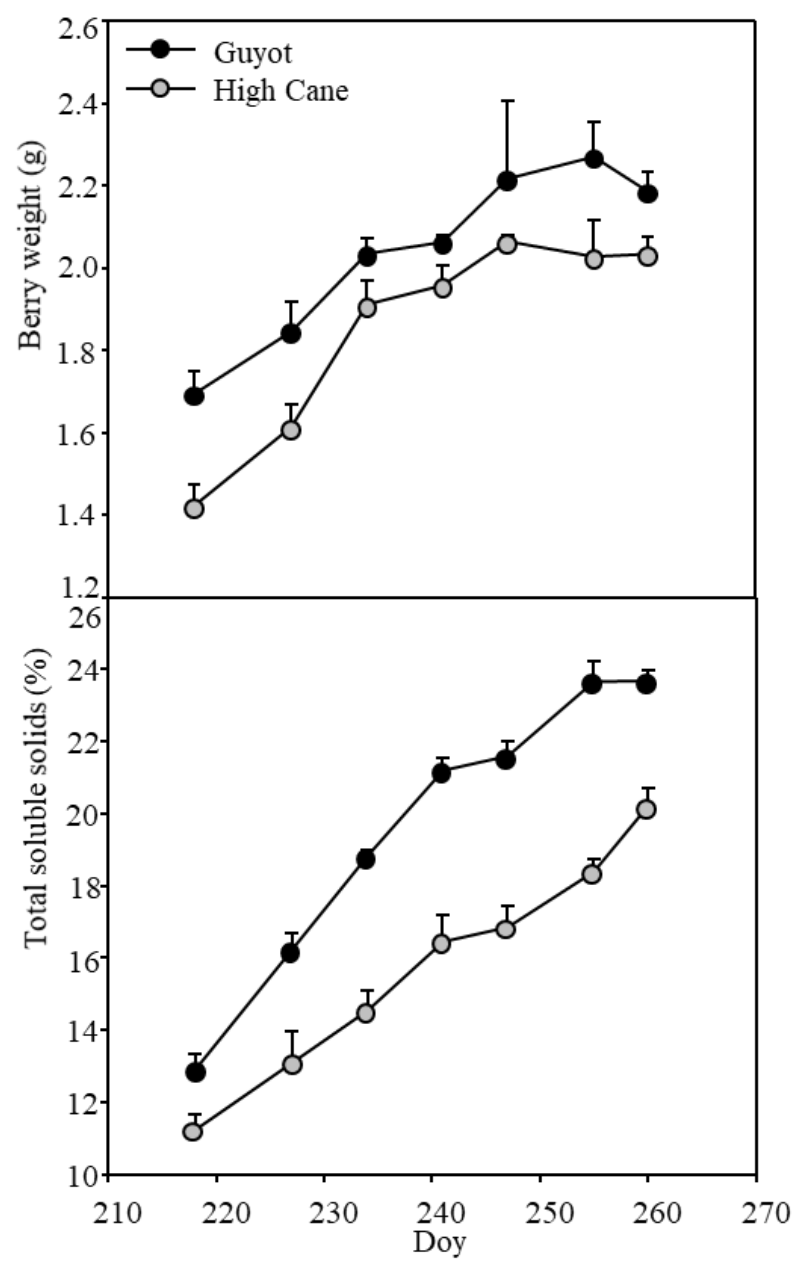

Figure 3. Berry weight and total soluble solids evolution.

Table 1. Vegetative and yield parameters compared in the two training systems. Within a column, mean separation performed with t-test is shown by lowercase letters.

\begin{tabular}{|c|c|c|}
\hline & Guyot & High Cane \\
\hline Shoot/vine $\left(\mathrm{n}^{\circ}\right)$ & $13 \mathrm{~b}$ & $16 \mathrm{a}$ \\
\hline Yield/vine $(\mathrm{kg})$ & $2.93 \mathrm{~b}$ & $5.54 \mathrm{a}$ \\
\hline Cluster/vine $\left(\mathrm{n}^{\circ}\right)$ & $7.3 \mathrm{~b}$ & $13.2 \mathrm{a}$ \\
\hline Cluster weight $(\mathrm{g})$ & $420 \mathrm{a}$ & $417 \mathrm{a}$ \\
\hline Berry weight $(\mathrm{g})$ & $2.19 \mathrm{a}$ & $2.04 \mathrm{~b}$ \\
\hline Fertility coefficient & $0.55 \mathrm{~b}$ & $0.84 \mathrm{a}$ \\
\hline
\end{tabular}

As regards the qualitative parameters of grape measured at harvest, the High Cane vines, in comparison to Guyot trained ones, showed a sugar concentration ( ${ }^{\circ}$ Brix) significantly lower (respectively of $21.21{ }^{\circ}$ Brix vs $23.68{ }^{\circ}$ Brix) and a titratable acidity significantly higher $(5.84 \mathrm{~g} / \mathrm{l}$ versus $5.07 \mathrm{~g} / \mathrm{l})$ associated to lower $\mathrm{pH}$
(Tab. 2). These differences are to be attributed to the altered ratio between the total leaf area and yield, statistically lower in the High Cane than in the Guyot, $0.88 \mathrm{~m} 2 / \mathrm{kg}$ vs $2.13 \mathrm{~m} 2 / \mathrm{kg}$. The growth of the lateral shoots stimulated by repeated topping in the High Cane trained vines helped to protect the bunches from excessive solar radiation and temperature increase, thus limiting damage from sunburn and the loss of acidity of the grapes. In addition, the lateral growth increased competition for carbohydrates and limited the accumulation of sugar in the berries.

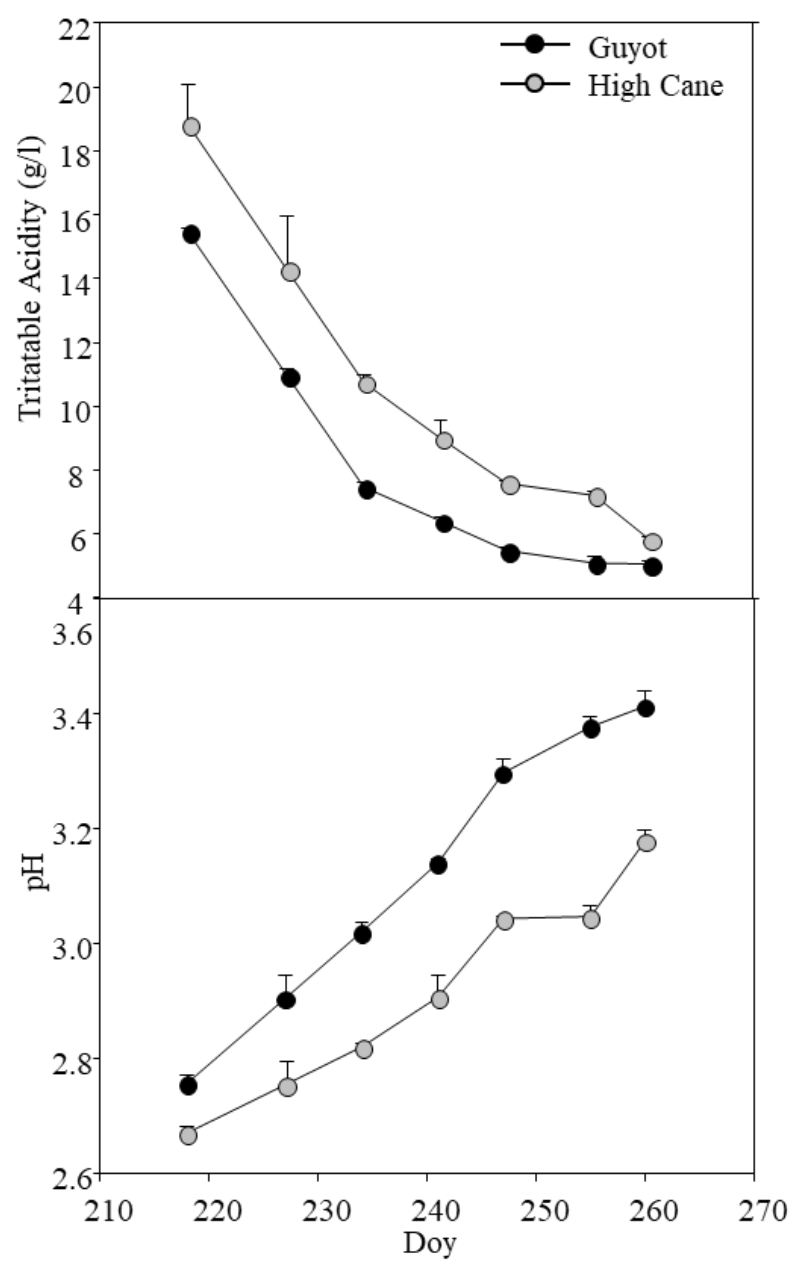

Figure 4. Titratable Acidity and $\mathrm{pH}$ evolution.

Table 2. Sugar concentration, Titratable acidity (TA), pH and leaf area and yield ratio, at harvest in the two training systems. Within a column, mean separation performed with t-test is shown by lowercase letters.

\begin{tabular}{|c|c|c|}
\hline & Guyot & High Cane \\
\hline Sugar concentration $\left({ }^{\circ}\right.$ Brix $)$ & $23.68 \mathrm{a}$ & $20.21 \mathrm{~b}$ \\
\hline $\mathrm{TA}(\mathrm{g} / \mathrm{l})$ & $5.07 \mathrm{~b}$ & $5.84 \mathrm{a}$ \\
\hline $\mathrm{pH}$ & $3.41 \mathrm{a}$ & $3.18 \mathrm{~b}$ \\
\hline Total leaf area/yield $\left(\mathrm{m}^{2} / \mathrm{kg}\right)$ & $1.71 \mathrm{a}$ & $0.79 \mathrm{~b}$ \\
\hline
\end{tabular}




\section{Conclusions}

The results obtained during the first year of the present study show significant and promising differences between the two training systems on yield per vine, grape ripening evolution and must composition at harvest. The main results can be attributed to the substantial reduction of total leaf area/yield ratio that decreased the photosynthetic potential. Reduction of sugar accumulation and delayed ripening can also help coping with global warming and climate change. In addition, the increase in the distance of the cane fruit from the ground, may allow to decrease the heat radiated from the ground to the grapes, helping to reduce the loss must acidity.

Another potential positive aspect, due to the greater distance of the cane from the ground, is the reduction of the risk of possible frost damage in spring.

\section{References}

1. V. Masson-Delmotte, P. Zhai, H.-O. Pörtner, D. Roberts, J. Skea, P.R. Shukla, A. Pirani, W. Moufouma-Okia, C. Péan, R. Pidcock, S. Connors, J.B.R. Matthews, Y. Chen, X. Zhou, M.I. Gomis, E. Lonnoy, T. Maycock, M. Tignor, T. Waterfield, IPCC (2018)

2. A. Palliotti, S. Tombesi, O. Silvestroni, V. Lanari, M. Gatti, S. Poni. Sci Hortic. 178, 43-54 (2014)

3. V. Lanari, T. Lattanzi, L. Borghesi, O. Silvestroni, A. Palliotti. Acta Horticulturae 978, 327-334 (2013).

4. O. Silvestroni, V. Lanari, T. Lattanzi, A. Palliotti, P. Sabbatini. Am. J. of Enol. and Vitic. 67, 407-418 (2016).

5. O. Silvestroni, V. Lanari, T. Lattanzi, E. Dottori, A. Palliotti. Aus. J. of Grape and Wine Res. 26, 363371, (2020)

6. M. Gatti, F.J. Pirez, G. Chiari, S. Tombesi, A. Palliotti, M.C. Merli, S. Poni. Frontiers in Plant Sciences 7, 659 (2016)

7. T. Frioni, S. Tombesi, O. Silvestroni, V. Lanari, A. Bellincontro, P. Sabbatini. Am. J. of Enol. and Vitic. 67, 419-425 (2016).

8. A. Palliotti, T. Frioni, S. Tombesi, P. Sabbatini, J.G. Cruz-Castillo, V. Lanari, O. Silvestroni, M. Gatti, S. Poni. Am. J. of Enol. and Vitic 68, 412-421 (2017)

9. O. Silvestroni, V. Lanari, T. Lattanzi, A. Palliotti Austr. J. Grape and Wine Res. 24, 478-486 (2018)

10. M. Gatti, F.J. Pirez, T. Frioni, C. Squeri, S. Poni. Aus. J. of Grape and Wine Res. 24, 305-316 (2018) 